\title{
Democracy and growth in pre-industrial countries
}

\author{
Democracia e crescimento em países pré-industriais
}

LUIZ CARLOS BRESSER-PEREIRA*

RESUMO: Este trabalho distingue três tipos de país (rico, de renda média e pré-industrial) e centra-se no último, que, ao contrário dos outros dois, não completou suas revoluções industrial e capitalista. Um país pré-industrial pode ser governado bem e sob a democracia? Hoje a democracia é um valor universal e, portanto, os países estão sob a pressão do Ocidente e de sua própria sociedade para serem democráticos, embora suas sociedades não sejam suficientemente maduras, nas quais o excedente econômico seja apropriado pelo mercado. De fato, nenhum país completou sua revolução industrial e capitalista no âmbito de uma democracia mínima. Além disso, o país pré-industrial é extremamente difícil de governar, porque ele geralmente não tem uma nação forte e estado capaz. Esta dupla pressão representa um grande obstáculo ao seu desenvolvimento.

PALAVRAS-CHAVE: capitalismo; democracia; estado; desenvolvimento econômico; países em desenvolvimento; distribuição de renda.

ABSTRACT: This paper distinguishes three types of countries (rich, middle-income, and preindustrial) and focus on the latter, which, in contrast to the other two, didn't complete their industrial and capitalist revolutions. Can pre-industrial countries be governed well and under democracy? Today democracy is a universal value, and, so, these countries are under pressure from the West and from its own society to be democratic, even though they do not dispose of mature enough societies in which the economic surplus is appropriated through the market. In fact, no country completed its industrial and capitalist revolution within the framework of even a minimal democracy. Additionally, pre-industrial countries are extremely difficult to govern because they usually don't have a strong nation and capable states. This double pressure represents a major obstacle to their development.

KEYWORDS: capitalism; democracy; state; economic development; developing countries; income distribution.

JEL Classification: P01, P16

\footnotetext{
* Professor emérito da Fundação Getulio Vargas. E-mail: bresserpereira@gmail.com. 14/agosto/2015; aprovado: 14/junho/2016.
} 
In the 1970s, social scientists discussed authoritarian-modernizing military regimes; in the 1980s, the topic was democratic transition; in the 1990s, the possible consolidation of democracy; in the 2000s, the quality of democracy in developing countries. Throughout this period, democratization was effective in the best-organized countries, which built relatively capable states and a class of industrial business entrepreneurs, and were able to carry out the industrial revolution. These countries became middle-income countries with consolidated democracies. The others remained poor or pre-industrial countries. Nevertheless, a sizable number of them moved to democracy under the pressure of domestic popular demand and of richer countries, despite the fact that their economy and their society did not possess the maturity for that. Thus, the new democracies proved unstable and of low quality.

The political challenges that pre-industrial countries face are many: strengthening the nation, building a capable state, completing the capitalist revolution (by forming an autonomous nation-state and realizing the industrial revolution), making the catching up, and achieving democracy while reducing economic inequality. ${ }^{1}$ But the obstacles they face are many. Some come from the society's high level of heterogeneity and lack of cohesion, which opens room for economic populism. Other challenges come from the soft power practiced by rich countries or the West, which sees "foreign savings" (current account deficits and foreign indebtedness) as condition to growth, at the same time that impedes the adoption of the same developmental policies that rich and middle-income countries adopted when they industrialized earlier. ${ }^{2}$

My objective in this paper is to discuss the relationship between democracy and the capitalist revolution in these pre-industrial countries. My main focus is the Latin-American countries, but I believe the analysis is also valid for other pre-industrial countries. My main question is, what are their chances of having good governments, realizing their capitalist revolution, and making the transition to a consolidated or stable democracy $?^{3}$ To answer this question, I will, first, look at what is required to succeed. I will briefly review the paths to capitalism and democracy, and show that to have a consolidated democracy each country must, first, make its national and industrial revolution, what will happen in the framework of a developmental state. Following, I will discuss how important is a capable state to go ahead with economic development and the improvement of the quality of democracy, and the obstacles to be faced: economic populism, the interests of the West, and the dependency of the local elites.

\footnotetext{
${ }^{1}$ The nation, here, is the people shares a history and a common destiny, and forms with its state and its territory a nation-state or country; the state is the law and the organization that guarantees it.

${ }^{2}$ See on that Ha-Joon Chang (2002) and Erik Reinert (2007).

${ }^{3} \mathrm{~A}$ consolidated democracy is one that has matured to the point where it is unlikely to slide back toward an authoritarian regime.
} 


\section{THE PATHS TO CAPITALISM AND DEMOCRACY}

Countries may be categorized as rich or developing, the latter being either middle-income ones like Brazil, Argentina, China and India, which have already completed their industrial or capitalist revolution, or pre-industrial countries as Egypt, Bolivia, Bangladesh and Mozambique. There are many paths that countries may take to industrialize, to catch up, and make the transition to democracy. I will adopt a theoretical approach that makes a consolidated democracy dependent on the country having previously realized its industrial and capitalist revolution. When the country turns democratic before that, the appropriation of the economic surplus will not be achieved in the market, but will be highly dependent on the direct control of the state, and the ruling class will veto democracy. ${ }^{4} \mathrm{~A}$ pre-industrial country will follow approximately the following sequence of historical stylized changes:

1. It develops exports of commodities from which it derives Ricardian rents that make them economically viable, but at the cost of the Dutch disease;

2. It builds an autonomous nation-state;

3. It adopts a developmental strategy;

4. It neutralizes the Dutch disease, so assuring competitiveness to its manufacturing industry;

5. It achieves its industrial and capitalist revolution, thus opening room for catching up;

6. It proceeds toward the transition to democracy; and

7. It improves the quality of that democracy while experiences sustained growth.

I acknowledge that this stylized historical path suffers from excessive generalization, given that countries differ in size, history and culture. However, I am persuaded that all modern societies strive for economic development and for democracy, which, when successful, goes through a succession of stages that don't differ very much from the ones I am proposing. The left in Latin America criticized Walt W. Rostow (1960) when he published his book on the stages of economic development, but, today, those who reject the idea of stages and want all countries to adopt the same institutions independent of their stage of development are rather on the right, than on the left end of the political spectrum.

The history of mankind and the history of each people has a central divide: the capitalist revolution - the period in which a people moves from an agrarian or mineral to an industrial society, from a society coordinated by religion and the ancient state to a society coordinated by the law of the modern state and by the market. Second, the two final stages of such capitalist revolution (the formation of

\footnotetext{
${ }^{4}$ See Bresser-Pereira, "Democracy and capitalist revolution" (2012).
} 
an effectively autonomous nation state and the realization of the industrial revolution) takes place within the framework of a developmental state-a state that assigns priority to economic development, is nationalist in economic terms, and combines market coordination with moderate state intervention. ${ }^{5}$ Third, the industrial and capitalist revolution happens either under a purely authoritarian regime, as it did in the United Kingdom, Japan, Russia and Brazil, or under a liberalauthoritarian regime (where civil rights were already assured, but universal suffrage was not), as it did in the United States. ${ }^{6}$ Fourth, when the country makes its transition to democracy after the industrial revolution, democracy will be consolidated. To be sure, a country may make the transition to democracy before completing its capitalist revolution, but the resulting democracy will be unstable.

In the countries that are rich today, the sequence of economic and political events since the eighteenth century followed approximately the order above. The same sequence applies to the middle-income countries that made their capitalist revolution in the $20^{\text {th }}$ century, with one difference: they had to face the power of the first countries to industrialize. In Latin America, where political independence was achieved in the early nineteenth century, economic and cultural dependence remained strong, given the type of mercantile and plantation colonization they had; this was very different to the colonization by settlement that happened in the Northeast of the United States. ${ }^{7}$ Only in the 1930s were a few Latin American countries such as Brazil and Mexico able to profit from the Great Depression. That weakened the West, and allowed Brazil and Mexico to adopt developmental policies and realize their capitalist revolution to the extent where, since the 1980s, their democracies have been consolidated ones. Different was the behavior of East Asian countries, where cultural dependency was smaller. These countries followed Japan's example, made their industrial and capitalist revolution since the 1950s, and today are rich countries.

\footnotetext{
${ }^{5}$ In this sense, the first historical form of developmentalism was mercantilism; other forms were Bismarckism, national-developmentalism and Fordism.

${ }^{6} \mathrm{I}$ am aware that most Americans believe that the United States is democratic since the time of the founding fathers, but I adopt a minimum concept of democracy which requires the rule of law and universal suffrage. As a liberal country, the United States assures the civil rights for long, not the universal suffrage, which only was achieved in the end of the nineteenth century. As we can read in the Wikipedia (consulted 23/11/15) on the universal suffrage, "The United States theoretically adopted full male suffrage with the Fifteenth Amendment to the Constitution in in 1870, but this was not practically implemented in the South until the Voting Rights Act of 1965". Female suffrage was achieved in 1920.

${ }^{7}$ Some economic historians, based on Angus Maddison's studies for the OECD, (according to which the per-capital GDP in Latin-American countries was only half that of the United States' in 1820 and around one-fifth one hundred years later) have concluded that the roots of Latin America's late development lie in the $19^{\text {th }}$ century. These historians were misguided by statistics, failing to understand the decisive role that each country's industrial revolution played. The fact that per capita income in the United States in the early 1820 s was just twice as high as Brazil's is misleading. In fact, the American industrial revolution was already under way in the mid-1800s, enabling elevated rates of growth; only one hundred years later the more successful Latin-American countries achieved this stage and began growing rapidly. And many Latin-American countries are still pre-industrial.
} 
From the sixteenth to the eighteenth centuries the European countries had no power to colonize Asian and African societies. In the late XVIII and early XIX century, the UK, France, Belgium and the Netherlands underwent their industrial revolutions. In consequence their economic and military power increased, and made them able to reduce those two continents to the colonial condition. With the demise of colonialism after World War II, colonized countries became independent. A few societies in East Asia soon embraced a developmental model copied from Japan, made their industrial revolution, and began the catching up process. Three of them-South Korea, Taiwan and Singapore-are today rich and democratic countries. ${ }^{8}$ For the others, catching up has been essentially an illusion. As we see in Table 1, where wee see the per capita growth rates by quintiles between 1960 and 2010 , the growth rate of the $40 \%$ poorest countries (where the pre-industrial countries are) were substantially lower than the richest $20 \%$ and than the average growth. Kraay and McKenzie (2014) also conclude from this table that the "poverty trap" models were not validated, as the poorest quintile growth was above average. They are right because in a pre-industrial country the first stage of development takes place when it is able to profit its natural resources to export some commodity. Yet, the radical fall in the growth rates of the second poorest quintile suggests that the fundamental obstacle that countries face is to industrialize. Once this obstacle is surmounted, growth rates increase and turn near the average: there is not catching up, but growth became relatively self-sustained.

Table 1: GDP per capita growth, by quintiles of the initial income distribution, 1960-2010, 110 countries

\begin{tabular}{|c|c|}
\hline & $\begin{array}{c}\text { GDP growth per capita, yearly } \\
(\%)\end{array}$ \\
\hline Quintile poorest & 2.2 \\
\hline Second quintile & 0.9 \\
\hline Third quintile & 2.0 \\
\hline Fourth quintile & 2.4 \\
\hline Richest quintile & 2.1 \\
\hline Average & 1.9 \\
\hline
\end{tabular}

Source: Pen World Tables 7.0, in Aart Kraay e David McKenzie (2014): 133.

It is not difficult to understand why countries achieved consolidated democracy only after having completed their national and industrial revolution. In a pre-capitalist society, the ruling regime is in principle oligarchic, and the alternation of power that is essential to democracy would mean a loss of wealth and in-

\footnotetext{
${ }^{8}$ After Kaname Akamatsu's pioneering work (1962) on the "flying geese"-a metaphor for countries that copied the Japanese model in stages—a rich literature developed on the topic.
} 
come for the defeated faction of the oligarchy. When a society becomes capitalist and the bourgeoisie becomes the dominant class, this veto over democracy loses meaning, as the alternation of powers no longer has such negative consequences for the political party that loses election. Besides, the two new ruling classes-the bourgeoisie and the rising technobureaucratic class-are large enough to require institutions enabling its more ambitious members to ascend to political power. Therefore, in capitalist societies, after a liberal-authoritarian period in which suffrage depends on income or property, and under the pressure of the popular classes and the middle classes, the government shifts to democracy sooner or later. First, it moves to some kind of "democracy by elites", which attends the minimal concept of democracy-it guarantees the civil rights or liberties and universal suffrage-and later to a higher quality of democracy. But this democracy, rooted in capitalism, is born consolidated, because at this level of development, democracy is in everyone's interest.

\section{STAGES AND QUALITY OF DEMOCRACY}

When, in early twentieth century, countries, that are rich today, achieved universal suffrage, ${ }^{9}$ this first historical form of democracy was what we could call an "elites' democracy" or "liberal democracy"-a form of government that meets the criteria for democracy only minimally, and, therefore, its quality is minimal. This form of democracy is also referred to as "Schumpeterian", because it corresponds to the democracy that Joseph Schumpeter observed and defined, based on his experience in Europe after World War I. According to his view, politicians faced periodic and competitive elections where the people elected them, but then they governed only with the elites, practically ignoring the people. ${ }^{10}$ Liberal political theory calls all types of democracies "liberal democracy", provided that they meet the minimal requirements: the rule of law and universal suffrage. By using such terminology, liberals try to convey that all democracies are liberal. This means that all of them respect the liberal or civil rights. Yes, they do; but not all are just liberal, they may be additionally "social" in so far that they enhance social rights. United States, for instance, is just a liberal democracy, while countries like Sweden and France are "social democratic".

The political framework changed in the rich countries of Western and Northern Europe after World War II, where countries took a step ahead by building a welfare state, which assured a broad range of social rights to their people. Such increase in collective consumption meant a more egalitarian and a relatively

\footnotetext{
${ }^{9}$ Relatively "universal”, as women remained excluded. The United States, the United Kingdom, and other countries, started to extend the right to the female vote after the First World War, over the course of the 1920s; Italy and France only did so after the Second World War.

${ }^{10}$ Schumpeter (1942).
} 
more efficient form of increasing standards of living and the quality of life (more efficient in the sense of being less costly than individual consumption). Thus, democracy in these countries ceased to be simply elites' democracies, and became "public opinion democracies". Politicians now listen to citizens insofar as their preferences associated with certain political issues are reflected in public opinion. And, in a third stage, insofar as they attend to the demands of citizens for health care, education, social security, social assistance, as well as demands for some degree of security and working quality in the labor contracts, they may be called "social democracies".

Through these three stages of democratization-elites' democracy, public opinion's democracy, and social democracy - the democratic state ceased to be a mere instrument of the ruling classes and began to reflect the interests of popular classes to varying degrees. Democratization is not restricted to the state, but extends to the nation and to civil society. Civil society ceased to be an expression only of the interests of the high bourgeoisie.

The third stage of democratization-the social stage-has been under attack by the neoliberal class coalition of rentier capitalists and financiers since the 1980s. ${ }^{11}$ Given the competition from some developing countries, particularly from the fast-growing East Asian countries, and Brazil and Mexico since the 1970s, rich countries have lost some of their competitiveness. This fact plus the increase in the power of labor in these countries was the reason for the reduction of the profit rate and for the economic crisis faced by the West in the 1970s. The neoliberal coalition that turned dominant in the early 1980s was a method of counteracting this problem by dismantling the welfare state and by reducing the protections found in labor contracts. Thirty-five years later, after the 2008 global financial crisis, we see that neoliberalism failed in dismantling the welfare state, but has been relatively successful in making labor contracts more flexible, and in causing the precarization of labor.

The next stage of democratization, the fourth stage, is participatory democracy-under which citizens are capable of taking part in political decisions up to a point. It is modest and realistic when compared with "deliberative democracy", because it does not require the direct participation of people in deliberation, except in exceptional cases of referenda; it just requires that they be heard. Actually, participatory democracy, which is associated to several forms of social accountability, and, to a lesser extent, referenda may be seen in countries and cities at very different levels of development. In Switzerland and California, for example, referenda-actually a form of direct democracy-become increasingly frequent. In middle-income countries like Brazil participative democracy has also made some progress. The 1988 Brazilian Constitution makes room for several forms of participative democracy via municipal committees and national conferences for the

\footnotetext{
${ }^{11}$ While the neoliberal class coalition was very narrow, the Fordist coalition that preceded it was a broad and developmental class coalition.
} 
state's major social services, which allowed an active although limited participation. In addition, the Porto Alegre Participative Budget experience became a benchmark for a large number of participatory experiments in other countries.

Through these stages the quality of democracy increases in tandem with the reduction of political and economic inequality. In the rich world, progress on such terms happened since the eighteenth century, but stopped around 1980 when the Neoliberal Years turned dominant. When capitalism is left to the forces of the market it is, by nature, unequal. Among many other researches, Branko Milanovic (2007), Thomas Piketty (2013) and Anthony B. Atkinson (2015) vigorously document the point. The logic of democracy is different; it follows the principle of civil and equal political rights for all—something that can only become a reality when deliberate political action makes capitalism consistent with a reasonable level of economic equality.

For these reasons, the level of economic equality is a measure of the quality of democracy. When economic inequality is great, political equality (universal suffrage and even condition in electoral competition) and civil equality ("equality before the law") become relative principles. Rich and middle-income countries improved their democracy by moving through such stages. When inequality increases, as has been happening dramatically in the last 35 years, the quality of democracy regresses. It is in this negative background, in which rich countries feel threatened by the emergence of low wage developing countries, and insecure on keeping these countries under their leadership that pre-industrial countries are supposed to industrialize. In such circumstances, will they be able to industrialize, turn democratic and improve the quality of their democracies?

\section{A CAPABLE STATE}

For each country to realize the national and industrial revolution, to make the transition to democracy, and to improve its quality a country depends on the strength and dynamism of its civil society as much as on the capability of the state. It is the interpenetration of civil society and of the elected and non-elected public bureaucrats that ensures the state's legitimacy and capacity; it is such embedded character of the public bureaucracy that enables the state to foster economic development within the framework democracy. But we also know that in pre-industrial countries, civil societies are weak and that capacity is very limited.

It is difficult to define what constitutes a capable state. I list bellow some of its characteristics:

1. must be strong or "republican", i.e., able to defend itself from the individuals and groups engaged in rent seeking;

2. must have a reasonable number of public-interest oriented politicians and bureaucrats; 
3. must have a properly recruited and evaluated professional public bureaucracy capable of managing the state apparatus in a managerial manner;

4. must have its finances in order and no debt in foreign currency-a currency that the state cannot issue, and, for that reason, represents a major threat to the state's sovereignty; and

5. must, above all, enjoy legitimacy — support from society—so that its laws are adopted by all citizens, and, for that reason, effectively enforced.

When legitimacy is lacking, the law frequently fails to be applied, and the state proves to be weak. As Peter Evans pointed out, to the state to be capable its professional bureaucracy has to be embedded in society. ${ }^{12}$ This means that the government technobureaucracy is not a neutral third party, but is associated, on one side, with the business entrepreneurs, and, on the other, with the workers; and that these three classes form a class coalition that will be developmental and democratic-developmental if economic growth is the priority, democratic if the government is for the many, not for a small group.

A state becomes capable when it extends its power over all of society, when "statehood"-effective regulation by the state-pervades every social sector. ${ }^{13}$ If the logic of capital pervades all economic relations in capitalist societies, the logic of the modern state pervades more than that: pervades all social relations. The effective regulation by the state of the whole social system is the basic condition for the modern state to play its unique coordinating role, with assistance from the market and from other institutions. But this is a difficult condition to meet, because it suffers from the chicken and egg conundrum of what comes first: it assumes a reasonably cohesive nation and a relatively diversified and active civil society whose members are aware of their rights and obligations, which, on its turn, depends on the existence of a capable state that defines the core institutions and enforces them.

Finally, a capable state - principally in the capitalist revolution phase - is a developmental state. A capable state, which succeeds in industrializing or turning the country productively sophisticated, has always been a developmental state-a state that (a) is usually supported by a class coalition associating industrial entrepreneurs, urban workers and the public bureaucracy, (b) has as priority economic development, (c) is nationalist in economic terms insofar that capitalism is characterized by the competition among nation-states and the hegemony of the West, (d) and intervenes moderately but effectively in the economy to achieve national autonomy and growth, not in the competitive sector of the economy, where the market is a superior coordinative institution, but in the non-competitive sector (main-

\footnotetext{
${ }^{12}$ Evans (1992).

${ }^{13}$ Statehood is the translation from the original, "estatalidad" - a Spanish-language expression that Oscar Oszlak (1997: Introduction) used to designate the state's pervasive penetration into the whole society.
} 
ly the infrastructure) and in macroeconomic realm, where the market is definitely unable to assure stability and growth.

\section{POLITICAL AND ECONOMIC POPULISM}

Up to here I discussed in this paper the requirements of what a pre-industrial country needs in order to form an autonomous nation-state and make its industrial revolution. Now I will discuss the difficulties, the obstacles that pre-industrial countries face. In the introduction to this paper I affirmed that they face obstacles from within, as well as from without. The obstacles from within are related to the lack of cohesiveness of the nation and of civil society, and the consequently poor capacity of the state. The external obstacles originate from a double constraint imposed by the West on the pre-industrial countries today: they are not supposed to adopt developmental policies and institutions, and it is requested that they become democratic. This latter urging comes despite the fact that no country up to now has made its capitalist revolution within the framework of democracy.

Let us begin with the obstacles from within that pre-industrial countries face to build a capable state and industrialize. They are many. On the socio-political level they can be summarized in one expression: low social cohesiveness that results in a weak nation and an equally weak civil society. On the institutional level, institutions reflect domineering rather than contractual relations. The political consequence of all this is, first, that it will be very difficult to govern. A second consequence is that the political leader who will govern a pre-industrial country will probably be populist. Populist in which sense? If the political leader is just populist in political terms, he may be a hope for his country, because political populism is usually a signal that the people is beginning to participate from political affairs; if he is populist in economic terms, he will almost certainly fail to lead the country towards development and catching up. Economic populism is, by definition, a perverse form of managing the economy; it is the practice, often present in pre-industrial countries, of the government spending irresponsibly more than it collects. Economists identify and criticize a single kind of economic populism-fiscal populism, which occurs when the state or the public administration spends irresponsibly more than it receives, incurring high and chronic public deficits. But there is a second type of economic populism, "exchange rate populism" - when the country as a whole-the nation-statespends irresponsibly more than it receives in foreign money, incurring high and recurring current account deficits. Exchange populism is ignored by all liberals and most developmentalists, but is the fundamental cause of the balance-of-payment or currency crises to which developing countries are prone. Contrary to what liberal orthodoxy assumes such current account deficits are the outcome of excessive indebtedness of households and business firms, and not from the public sector, whose 
budget may be balanced..$^{14}$ Adding to the harm, such indebtedness usually finances consumption, not investment.

Current-account deficits are called "foreign savings", which suggests that they represent additional investment. But, given the high rate of substitution of foreign for domestic savings existing in developing countries, they usually result in more consumption rather than in more investments in so far as they appreciate the currency. We already saw that these countries should ideally exhibit a current account surplus, not a deficit. Yet, given the weakness of the nation and of civil society in pre-industrial countries and the lack of accountability of political leaders, the Dutch disease will not be neutralized and the growth of foreign indebtedness or "foreign savings" policy will be gladly adopted. This condemns these pre-industrial countries to low growth and a delay in realizing its capitalist revolution.

Additionally, they will often incur chronic fiscal deficits. Leaders will justify it with an appeal to a "vulgar" Keynesianism, which adopts a lax concept of insufficiency of demand. Liberal economists will criticize this fiscal populism for good reasons, while they ignore exchange rate populism. They do that for two reasons: first, because they assume that the exchange rate is volatile in the short-term, but balanced in the medium and long-term; and second, because they believe that the state has the autonomy to undertake fiscal policy, not exchange rate policy; that the exchange rate would be governed by the market, and that all attempts to control it would fail. Despite that belief, experience shows that this is not true.

A quite different problem is political populism. Populist leaders usually enable the earliest form of popular participation. This is so because the populist leader is, by definition, the politician who establishes a direct link with the popular classes without the intermediation of political parties and ideologies, which, it is interesting, are not yet part of the people's political culture. He is populist because he must have the support of the people. If, at the same time, he rejects economic populism, and adopts a developmental strategy, he may well be successful in leading his country's capitalist revolution. Conventional knowledge is critical of popular and developmental leaders that they call "populist" in a derogatory, anti-democratic sense. This criticism confuses economic populism, which is in principle negative, with political populism, which is not. Political populism is not a negative trait of a political leader, unless we consider statesmen like the American president Andrew Jackson and the Brazilian president, Getúlio Vargas, as bad politicians. Economic populism, on the other hand, is perverse by definition. The leaders who command the industrial revolution are always populist in political terms, and possibly also in economic terms. They are politically populists because in pre-industrial societies this is the first manifestation of democracy-more specifically, of the transformation of the poor into "masses" endowed with some political identity;

\footnotetext{
${ }^{14}$ High fiscal deficits corresponding to high current accounts are explained by the twin deficits hypothesis. But, when the currency is overvalued, the country may well have a large current account deficit while its fiscal accounts are balanced.
} 
second, they are political populists because society lacks the conditions for the emergence of ideologically defined political parties. Therefore, political populism carries no derogatory connotation.

Before the populist and developmental leader and his or her political party, the existing traditional parties merely reflect internal divisions of the elites, usually between a "conservative" and a "liberal" wing. The fact that the people understand and support the populist leader's discourse and elect him represents the first manifestation of the people's political participation in the country's destiny. This has been true even in the United States, which was never as poor as the Latin American countries; in the 19th century Andrew Jackson was the first to become president without being a member of the dominant aristocracy. In his administration, he proved to be a classic populist leader and therefore made his country move toward democracy from oligarchy. ${ }^{15}$ In 20th century Latin America, Getúlio Vargas was a populist leader and a great statesman who captained Brazil's industrial and capitalist revolution. Juan Domingo Perón, in Argentina, was also a populist, but his inability to challenge "el campo" (the commodities exporters, who were more powerful than the "coffee" exporters in Brazil) was one of the reasons for his failure to industrialize the country. And that industrialization is the condition that was necessary to avoid the economic decadence of the country that resulted in the second half of the 20th century.

\section{RICH COUNTRIES’ INTERESTS AND DEPENDENCY}

The first countries to realize their industrial revolutions became powerful enough to dominate peoples in Asia and Africa, and to impose their interests on Latin America. Industrial or modern imperialism was born. Colonial rule over Africa and Asia in the nineteenth century and first part of the twentieth century ended with World War II. After the war, during the Golden Years of Capitalism, the relations between rich and developing countries improved because the dominant Keynesianism suggested that interest of rich and poor countries could align, and mainly because the United States, then engaged in the Cold War, was interested in strengthening the countries under its influence. In addition to supporting the European countries with the Marshall Plan, the United States contributed to the agrarian reform and to the economic planning in South Korea and Taiwan; in Brazil, the Brazil-United States Mixed Commission (1950-53) contributed to developing the economic planning capacity of the country.

This picture began to change in 1959, when the Cuban Revolution led the United States to support military regimes in Latin America. This changed definitely in the 1980s because, in the preceding decades some countries-originally the newly industrialized countries (NICs) (South Korea, Taiwan, Singapore, Brazil and

${ }^{15}$ Benson (1969), Schlesinger Jr. (1946). 
Mexico) that had been able to strengthen their respective nations and achieve industrial and capitalist revolutions, in the 1970s-began to export manufactured goods to rich countries, benefiting from lower wages. This was a major threat to the West and particularly to the United States, which, at that time, was facing a domestic economic crisis. Yet, in the following decade, the United States resumed growth, while many developing countries fell into the major foreign debt crisis of the 1980s and stagnated. They resumed growth in the 1990s, but at much lower rates, except for some Asian countries between which two giant ones-China and India.

At the same time that the United States resumed growth, it moved from Keynesianism to neoliberalism-an ideological tool that proved effective in counter-attacking the rise of the NICs. Following the new rules of the game, the soft power imperialism gained all its traits. Now all countries that were indebted had to engage in structural adjustments and in neoliberal reforms aimed at dismantling the developmental state: privatization, trade liberalization, financial liberalization, and deregulation. At this point, the West offered renewed arguments or theories (neoclassical) to press pre-industrial countries to adopt these policies-something that it had lost during the years of classical developmentalism (1940s to 1960s). Now, as Ha-Joon Chang and Eric Reinert (already referred) demonstrated critically in the early 2000s, the West was able to block pre-industrial countries from adopting the very developmental policies that had worked in the nineteenth century to turn them rich. ${ }^{16}$.

There are two basic rules that all countries that realized their industrial and capitalist revolution late but successfully have followed. First, they copied the technology and the institutions of their predecessors who industrialized. Examples are Germany and Japan following Britain, France and the United States. Second, they became integrated in the capitalist world economy in a competitive way, exporting increasingly sophisticated manufactured goods. But the very same countries that took advantage of them previously - the richer countries or the imperial West - regard neither of these rules favorably. Now, these successful countries protect their intellectual property to the fullest extent possible, and hate to be copied. Second, they don't want competitors coming from the periphery of capitalism using cheap labor. Instead, as legitimate heirs of the colonial times, they feel entitled to occupy the domestic markets of developing countries with trade, finance and direct investments, That is: (a) to occupy them with sophisticated goods with high value added per capita and high salaries to be traded against commodities that are exactly the opposite; (b) to occupy them with finance, although such finance for most pre-industrial counties will be the source of increased consumption and increased foreign indebtedness, not of investment; (c) to occupy them with their multinational enterprises which are supposedly bringing capital and technology, but, as in the case of finance, they are only financing more consumption, not investment, and increasing the dependence of the developing countries.

${ }^{16}$ Ha-Joon Chang (2002), Erik Reinert (2007). 
The West wants and does obtain all this. Ideological hegemony or "soft power" combines persuasion with pressures. Using their powerful ideological apparatus the West is permanently persuading the people and particularly the elites of pre-industrial countries, but it does not hesitate to use recurring pressure and even direct force to make a country "cooperative". One priority is to persuade these countries that the "need" foreign capital to grow, despite the fact that growth is always associated to domestic, not foreign, savings. Pushing the country into being indebted in foreign currency is the essential imperialist strategy: the more the country gets indebted, the more its domestic market is occupied by the West, and the more it becomes dependent.

\section{THE DEMOCRACY PROBLEM}

Besides of this economic constraint there is also a political constraint. The consensus that democracy is the best of all political regimes is a relatively recent phenomenon. Among the great philosophers up to the nineteenth century, even those who came closer to the democratic ideal, like Rousseau and Stuart Mill, didn't, eventually, endorse it. Throughout almost all history, politicians and philosophers regarded democracy as a dangerous regime, being unstable and subject to abuse by demagogues; in the nineteenth century liberals opposed it with the argument that it would mean a dictatorship by the majority. This view only began to change in the turn to the twentieth century, as the more advanced countries, that already had liberal constitutional regimes that ensured the basic civil rights, one by one, beginning with New Zealand and Finland, accepted universal suffrage and became democratic. ${ }^{17}$ Today, when almost every wealthy country is democratic and a growing number of middle-income countries have achieved this status, it is now at the level of consensus to assume that democracy is the political regime that best overcomes the political challenges faced by modern societies; it is a regime that, as Carlos Nelson Coutinho noted, has become a universal value. ${ }^{18}$

Charles Tilly, who performed an in-depth study of the historic formation of nation-states, clearly saw the relationship between a capable state and democracy. According to him, "no democracy can work if the state lacks the capacity to supervise democratic decision making and put its results into practice". ${ }^{19}$ As Philippe Schmitter (2002: 1) noted,

...Liberalism, whether as a conception of political liberty or a doctrine about economic policy, may have coincided in some countries with

\footnotetext{
${ }^{17}$ Finland, in 1906, was the first country to endorse full universal suffrage; New Zeeland, 1893, was the first to assure masculine universal suffrage.

${ }^{18}$ Coutinho (1980) A Democracia como Valor Universal [Democracy as Universal Value].

${ }^{19}$ Tilly (2007: 15).
} 
the rise of democracy, but it has never been immutably or unambiguously linked to the practice of democracy, least of all, once this type of regime was transformed to include mass publics, popularly elected executives, specialized interest associations and boisterous social movements.

Jacques Rancière (2005) went a step beyond this and named this rejection by the wealthy in developing countries of real and possible democracies the "hatred of democracy". Rhetorically, conservative and neo-liberal elites praise democracy and eventually accept universal suffrage, but search to limit the manifestation of popular will in every possible way. Be it by making politicians dependent as a result of very expensive political campaigns with no public funding, or be it by systematically demoralizing politicians.

As I argued in the 2012 paper referred to previously and I am arguing in this paper, for democracy to be consolidated the nation-state must have completed its capitalist revolution, or, in other words, must be an industrial country or characterized by productive sophistication. Only after this will the society in this country be diversified and possess a large middle class, two features that characterize consolidated democracies. Even more important is that only after the economic system becomes capitalist-i.e., coordinated by the state and market instead of coordinated by religion and the state-will the economic surplus cease to be appropriated by the ruling classes through the control of the state to be appropriated in the market through profits-the alternation of powers that characterizes democracy will cease to be a unacceptable threat to the new dominant class, the bourgeoisie. Although the bourgeoisie fears democracy and would prefer liberal authoritarianism (the rule of law, but no universal suffrage), it was the first dominant class not to veto democracy. The reason for that is simple: the bourgeoisie allegiance to democracy stems from the fact that it appropriates the economic surplus by achieving profits in the market; the professional class's allegiance stems from it receiving high salaries and bonuses not through the state (as happened in pre-capitalist countries) but again in the market, through the exchange of "equivalent" values.

Once the capitalist revolution is achieved, democracy will materialize sooner or later. I see three reasons for that: first, the ruling class will not impose anymore a full veto to it; second, the poor will press for democracy; and, third, the rich will be many and will require clear rules on how to achieve or share political power among them. The authoritarian regime existing in the country may want to retain power after the capitalist revolution is completed, but the probability of this occurring is low. I can name only one country that should decidedly have become a democracy by now, but remains authoritarian: Singapore. ${ }^{20}$ The opposite outcome is more likely: democracy originated from the pressure of foreign powers, but, in this case, besides not being a consolidated democracy, it is practically impossible

\footnotetext{
${ }^{20}$ However, the recent death of Lee Kwan Yew, the highly successful politician who governed Singapore directly or indirectly for some 50 years, suggests that the country will soon turn democratic.
} 
to improve its quality. Institutions can be designed to improve the voting system, to regulate political parties, to increase the representativeness of governments and citizen participation therein, etc., but these institutions have little chance of being effectively enforced.

Democracy was born consolidated in the countries that first completed their capitalist revolution. The situation is today in pre-industrial countries is quite different. Their democracy originates not from the development of the country, but as the fruit of political emulation, of the domestic demand for democracy, and from the demand of the richer countries. In these countries, the formation of a truly autonomous nation-state and the industrial revolution should have priority over democracy, but the pressures, from within the country and from without push for immediate democracy. Take, for instance, Paraguay. The pressures to become democratic originate in the United States, in Brazil and Argentina (which are imperialist in relation to Paraguay), and in its own people. The people in pre-industrial countries demand democracy probably because they know that there is no assurance that the authoritarian political leader will have the public spirit and the ability to form a developmental class coalition, change the state into a developmental state, and initiate the country's industrial revolution. The number of authoritarian leaders that, instead, just represented the interests of the oligarchy from which they originate is immense. Thus, the possibility of what Wanderley Guilherme dos Santos (1978) called "instrumental authoritarianism" is not open today to pre-industrial countries. We will only know whether a given authoritarian regime was instrumental in achieving a country's industrial revolution or not after the fact. Today, for example, we know that Getúlio Vargas's authoritarianism was instrumental because he led the Brazilian national and industrial revolution and thereby created the conditions for a consolidated democracy in the country, but this could not have been foreseen in the 1930s, when he came to power.

All this means that populist and nationalist leaders of pre-industrial countries have no other alternative than to become democratic while searching to realize their capitalist revolution in this framework. These countries have to do what their predecessors-the countries that are today rich or middle-income-did not: they have to form a truly independent nation-state and make the industrial and capitalist revolution inside the framework of democracy. For sure, there are democracies in pre-industrial countries such as Paraguay, Bangladesh, Nigeria and Venezuela, but they are always low-quality, unconsolidated democracies. They are democratic by emulation and mainly because they are required to be so. When a political party loses elections, the opposition immediately claims fraud, even when there is none, and starts maneuvering to topple the government.

\section{INCLUDING THE “QUALITY OF DEMOCRACY” IN ITS CONCEPT}

It is within the framework of these considerations that the problem of the "quality of democracy" must be discussed-an issue that has been more intensely 
debated since the United Nations Development Programme (UNDP) report (2004). The quality of democracy depends on the level of economic and social development of the country, on the cohesiveness of its society, and on the capability of its state, which, in turn, are all related to whether or not a country has completed its capitalist revolution. By definition, in pre-industrial countries that have not completed it, the quality of their democracies will be low. Notwithstanding, supported by studies on the quality of democracy, rich countries have been considering it proper to intervene in these countries in several ways-from ideological pressure and support for liberal opposition groups that organize demonstrations and demand coups, all the way to armed intervention, particularly when their rulers are developmental and therefore embrace economic nationalism.

In the 1970s and 1980s, when political scientists like Juan Linz, Alfred Stepan, Guillermo O'Donnell, Philip Schmitter and Laurence Whitehead discussed democratic transitions, they made a point of adopting an objective and a minimal or formal definition of democracy. They wanted a simple criterion by which to judge whether or not a country had completed its democratic transition. They rejected the Marxist notion that capitalist democracies were merely "formal" democracies, because this turned difficult if not impossible to distinguish democracies from authoritarian regimes. Thus, the defined democracy following Robert Dahl's (1971) classical concept of "polyarchy", they did not include the level of economic equality among citizens in the concept of democracy. Even if they acknowledged the fact that the more substantive the equality among citizens, the better the quality of democracy would be, they believed it was essential to have a formal concept of democracy to prevent justifying authoritarianism in the name of increased social justice. Based on these considerations, I believe it is important to evaluate the quality of national democracies, but I reject the use of the quality of democracy for the purposes of judging whether a country is democratic or not. It is a mistake, similar to that incurred by Marxism in the 1950s and 1960s, when it criticized the democracies for being "formal" or "bourgeois". Today, however, it is no longer the Marxists, but the governments of rich countries and liberal journalists and political scientists who employ a very similar argument: they disqualify the democracies found in pre-industrial countries based on the quality of such democracies.

What they should be doing is evaluating the quality of a given democracy based on how much better or worse it is compared to others in the same stage of economic growth. But instead of doing this, they use the evaluation to disqualify the democratic nature of such democracy. They argue, for example, that the quality of a certain democracy is low because civil rights are not duly protected, and conclude, from this, that it cannot be considered a democracy. By embracing this approach, they commit a logical error: democracy is viewed as an either/or proposition; one can only measure the quality of democracy when it exists. But, even worse, by abandoning the well-established concept of minimal democracy (assurance of civil rights and universal suffrage) to include the quality of the democracy, they turn the concept of democracy back into something vague, and thereby justifying destabilizing interventions. 
Take, for instance, a country where the police resort to torture. Is it reasonable to disqualify the country as a democracy for this reason? I believe not. Were this criterion to be applied then perhaps the only democratic country in the Americas would be Canada. By keeping the concept vague, the West and its intellectuals feel justified in applying ideological pressure intended to destabilize democratic regimes; second, if this pressure does not suffice, they feel fit to justify supporting the "democratic opposition" to bring about what they call "regime change", which is nothing less than a coup d'état; and, third, if even this is not sufficient to create change, they stand ready to justify military intervention.

Based on this perverse use of the quality of democracy to disqualify democracy itself as failing to measure up, pre-industrial countries like Ecuador, Guatemala, Peru and Venezuela, or even a middle-income country like Mexico, may be deemed non-democratic, or, as Guillermo O'Donnell (2004: 44) says, "conditional political democracies". At this point, political scientists are supporting hegemonic soft power with rhetoric. A major intellectual like O'Donnell certainly did not have this purpose when he outlined the question of the quality of democracy, but his discussion of it created room for the West's imperial agenda. O'Donnell emphasized that an essential characteristic of democracies is the fact that the "wrong people" may be elected from the point of view of this or that individual or group of individuals, but such individuals or citizens will still have to accept the outcome of the ballots. And appropriately so. But to make quality a part of the concept of democracy and include into this quality a greater or lesser probability that countries may choose the wrong people may have facilitated, as Gabriela Ippolito (2004: 169) pointed out, “certain academics' decision to reclassify some democratic regimes as authoritarian”. The academic Ippolito references is Larry Diamond, a former researcher for the National Endowment for Democracy and a former editor of Democracy, the review that this American organization publishes in the guise of a scholarly review.

\section{CONCLUSION}

Summing up, in this paper I analyzed the major challenge that pre-industrial countries face. Such challenge is, on one side, to form an effectively autonomous nation-state and to realize its industrial revolution, thus completing its capitalist revolution, and, on the other side, going ahead with its transition to a consolidated democracy. To do that I began by defining the usual path to the capitalist revolution and to democracy that pre-industrial country will follow: it, first, proceeds the primitive accumulation, developing commodity exports; second, builds an autonomous nation-state and defines a industrialization or productive sophistication strategy; third, it achieves its industrial and capitalist revolution; forth, it proceeds to the transition to democracy. Once this is achieved, the country will possibly go through three stages of democratization-elites' democracy, public opinion's de- 
mocracy, and social democracy - a democratization process in which the quality of democracy increases.

But to do that the nation or the civil society must build a relatively capable state - which, to be so, must be "republican", i.e., able to defend itself from the individuals and groups engaged in rent seeking; must count with a reasonable number of public-interest oriented politicians and bureaucrats; must have its finances in order, particularly no major debt in foreign currency; ${ }^{21}$ and, above all, enjoys legitimacysupport from society-so that its laws are adopted by all citizens, and, for that reason, effectively enforced. These are general characteristics of a strong or capable state, which, particularly in the case of pre-industrial countries, must be a developmental state, i.e., a state that (a) has as priority economic development, (b) is nationalist in economic terms insofar that capitalism is characterized by the competition among nation-states and the hegemony of the West, (c) and intervenes moderately but effectively in the economy to achieve national autonomy and growth.

The pre-industrial country will face major difficulties to form a developmental state and industrialize due, on the socio-political to low social cohesiveness that results in a weak nation and an equally weak civil society, and, on the institutional level, institutions reflect domineering rather than contractual relations. In consequence, the nationalist leader that will eventually conduce the country to the capitalist revolution will be populist in political terms - he will have a direct relation with the people without the intermediation of political parties and defined ideologies. This will be not a problem if this leader rejects economic populism, i.e., fiscal and exchange rate irresponsibility. These are the domestic problem; the foreign one is modern, soft power or hegemony imperialism, which combines persuasion with economic pressure and, eventually, regime change - overthrowing the nationalist leader.

Pre-industrial countries will either be authoritarian or will have a non-consolidated or fragile democracy. What history tells is that only after the capitalist revolution was achieved in a country, if it is already a democracy, such democracy will be consolidated, or, if its not, when eventually the country democratizes, the ensuing democracy will be consolidated. And the quality of democracy, which was necessarily poor - an elites' democracy - while the country was pre-industrial, will have opportunity to improve as economic growth goes on, society turns more educated, and citizens, more aware of their rights and obligations.

\section{REFERENCES}

Akamatsu, Kaname (1962) “A historical pattern of economic growth in developing countries”, Journal of Developing Economies, 1(1) March-August: 3-25.

Atkinson, Anthony B. (2015) Inequality: What can be Done? Cambridge: Harvard University Press.

\footnotetext{
${ }^{21}$ For a state to have a debt in its own currency is no problem insofar that it is always able to print it, while to get indebted in foreign currency represents a major risk, actually a sovereign risk.
} 
Benson, Lee (1969) The Concept of Jacksonian Democracy: New York as a Test Case, New York: Athenaeum.

Bresser-Pereira, Luiz Carlos (2008) “Dutch disease and its neutralization: a Ricardian approach”, Brazilian Journal of Political Economy 28 (1) January: 47-71.

Chang, Ha-Joon (2002) Kicking Away the Ladder: Development Strategy in Historical Perspective. London: Anthem Press.

Coutinho, Carlos Nelson (1980) A Democracia como Valor Universal. São Paulo: Livraria Editora Ciências Humanas - Hucitec.

Dahl, Robert A. (1971) Polyarchy. New Haven, CT: Yale University Press.

Evans, Peter (1992) "The state as problem and solution: Predation, embedded autonomy, and structural change", in Stephan Haggard \& Robert Kaufman, eds. The Politics of Economic Adjustment. Princeton: Princeton University Press, 1992.

Gellner, Ernest (1993) "The coming of nationalism and its interpretation: the myths of nation and class", in Gopal Balakrishnan, ed. Mapping the Nation. London: Verso: 98-145.

Huntington, Samuel P. (1968) Political Order in Changing Societies, New Haven: Yale University Press.

Ippolito, Gabriela (2004) "In search of a new paradigm: quality of democracy and human development in Latin America”, in Guillermo O’Donnell, Jorge Vargas Cullell and Osvaldo M. Iazzeta, eds. (2004): 168-175.

Kraay, Aart and David McKenzie (2014) "Do poverty traps exist? Assessing the evidence", Journal of Economic Perspectives 28 (3): 127-148.

Milanovic, Branko (2007) Worlds Apart: Measuring International and Global Inequality, Princeton, NJ: Princeton University Press.

O'Donnell, Guillermo (1973) Modernization and Bureaucratic Authoritarianism: Studies in South American Politics. Berkeley: Institute of International Studies of the University of California, Berkeley, Modernization Series 9.

O’Donnell, Guillermo (2004) "Human development, human rights, and democracy", in Guillermo O’Donnell, Jorge Vargas Cullell and Osvaldo M. Iazzeta, eds. (2004): 9-92.

O’Donnell, Guillermo, Jorge Vargas Cullell and Osvaldo M. Iazzeta, eds. (2004) The Quality of Democracy: Theory and Applications. Notre Dame: Indiana University Press.

Oszlak, Oscar (1997) La Formación del Estado Argentino, Buenos Aires: Editorial Planeta.

Piketty, Thomas (2013) Le Capital an XXème Siècle, Paris: Seuil.

Poulantzas. Nicos (1978 [2001]) State, Power, Socialism. London: Verso. Originally published in French in 1978.

Rancière, Jacques (2005 [2014]) The Hatred of Democracy. Originally published in French, 2005.

Reinert, Erik S. (2007) How Rich Countries got Rich... and Why Poor Countries Stay Poor. New York: Carroll \& Graf.

Rostow, Walt W. (1960) The Stages of Economic Growth. Cambridge: Cambridge University Press.

Santos, Wanderley Guilherme dos (1978) Ordem Burguesa e Liberalismo Político, São Paulo: Duas Cidades.

Schlesinger Jr., Arthur M. (1946) The Age of Jackson, London: Eire and Spotswood.

Schmitter, Philippe C. (2006) 'A sketch of what a 'post-liberal' democracy might look like', Central European Political Science Review, 2006, 7, 23-24, 9-19.

Schumpeter, Joseph A. ([1942]1950) Socialism, Capitalism, and Democracy. New York: Harper \& Brothers, third edition, 1950.

Tilly, Charles (2007) Democracy. Cambridge: Cambridge University Press.

United Nations Development Programme - UNDP (2004) Democracy in Latin America. New York: United Nations Development Programme, Project on Democracy in Latin America, directed by Dante Caputo. 